\title{
New distribution record of deep-sea mussel, Bathymodiolus aduloides (Mollusca: Bivalvia: Mytilidae) from a hydrothermal vent, Myojinsho
}

\author{
TOMOKO KOITO $^{1}$, JUN HASHIMOTO ${ }^{2}$, SUGURU NEMOTO ${ }^{3}$, MADOKA KITAJIMA $^{3}$, MITSUGU KITADA $^{3}$ \\ AND KOJI INOUE 4 \\ ${ }^{1}$ College of Bioresource Sciences, Nihon University, 1866 Kameino, Fujisawa, Kanagawa, 252-0880, Japan, ${ }^{2}$ Faculty of Fisheries, \\ Nagasaki University, 1-14 Bunkyo, Nagasaki, 852-8521, Japan, ${ }^{3}$ Enoshima Aquarium, 2-19-1, Katasekaigan, Fujisawa, Kangawa, \\ 251-0035, Japan, ${ }^{4}$ Atmosphere and Ocean Research Institute, The University of Tokyo, 5-1-5, Kashiwanoha, Kashiwa, Chiba, \\ 277-8564, Japan
}

\begin{abstract}
From the deep-sea hydrothermal vents and cold seeps ecosystems, more than 600 species containing many endemic species have been discovered. The deep-sea mussels of the genus Bathymodiolus are dominant species at deep-sea hydrothermal vents and cold seeps throughout the world. They are known to rely on the nutrients produced by the chemosynthetic symbiont in their gills. In 2009, we found a colony of bathymodiolin mussels at a hydrothermal vent of Myojinsho (Myojin Reef), which is a hardly investigated area. Myojinsho lies in the northern segment of the Izu-Ogasawara (Bonin) Arc and had been volcanically active until recently. We collected specimens from the colony using a remotely operated vehicle. We identified them as Bathymodiolus aduloides by morphological observation and phylogenetic analyses using mitochondrial DNA sequencing. We could not find any other species of mussels during the dive. This result is interesting because this species has not been discovered from hydrothermal vents in this region; the dominant species in this region, including the neighbouring Myojin Knoll Caldera, is B. septemdierum.
\end{abstract}

Keywords: Bathymodiolus aduloides, cold seep, hydrothermal vent, Myojinsho

Submitted 7 February 2012; accepted 23 February 2012

\section{INTRロロபCTIDN}

Deep-sea hydrothermal vents and cold seeps ecosystems, depending on chemoautotrophic primary production, occur in a variety of locations throughout the global ocean (Van Dover et al., 2002). A variety of endemic organisms have been discovered from these environments.

The deep-sea mussels of the genus Bathymodiolus are one of the dominant groups of invertebrate at hydrothermal vent and cold seep ecosystems. Twenty-two species have been discovered thus far, from deep-sea hydrothermal vents on spreading ridges, back-arc basins and cold water seeps along subduction zones in the world (Miyazaki et al., 2010): some of the species are vent-specific, some are seep-specific species and some are found in both environments. The mussels of this genus harbour chemosynthetic symbionts (thioautotrophic bacteria, methanotrophic bacteria, etc.) in their gills, and are essentially dependent on the organic substances produced by the symbionts (Felbeck, 1983).

It is considered that Bathymodiolus expanded their habitat from shallow to deep water using sunken woods and whale

Corresponding author:

T. Koito

Email: koito.tomoko@nihon-u.ac.jp carcasses, as an 'evolutionary stepping stone' (Distel et al., 2000), and phylogenetic analyses have revealed the paraphyletic structure of the genus recently (Kyuno et al., 2009; Lorion et al., 2010). However, how bathymodiolin mussels have maintained and expanded their distribution area in the hydrothermal vent areas, which are patchily distributed and are temporally unstable, is still not fully understood.

Thus, it is important to accumulate the information about distribution of bathymodiolin mussels at various areas.

Japan is a point where the four tectonic plates, the Eurasian Plate, the Pacific Plate, the Philippine Sea Plate and North American Plate meet, and thus many hydrothermal vents and cold seeps have been discovered around there. These vents and seeps are a suitable field to study the ecology of chemosynthesis-dependent organisms. We are interested in the populations of deep-sea mussels around Japan. In 2009, we visited Myojinsho (Myojin reef), a submarine caldera located about $420 \mathrm{~km}$ south of Tokyo, approximately $9 \mathrm{~km}$ east-north-east of the Bayonnaise Rocks and $20 \mathrm{~km}$ south of Myojin Knoll caldera (Figure 1), and which lies in the northern segment of the Izu-Ogasawara (Bonin) Arc (Iizasa et al., 1992). Myojinsho has erupted more than 20 times since 1869, including explosive eruptions accompanying dome growth and destruction that occurred during 1952-1953. Even after that eruptions were observed sporadically until the 1970s (Fiske et al., 1998). 


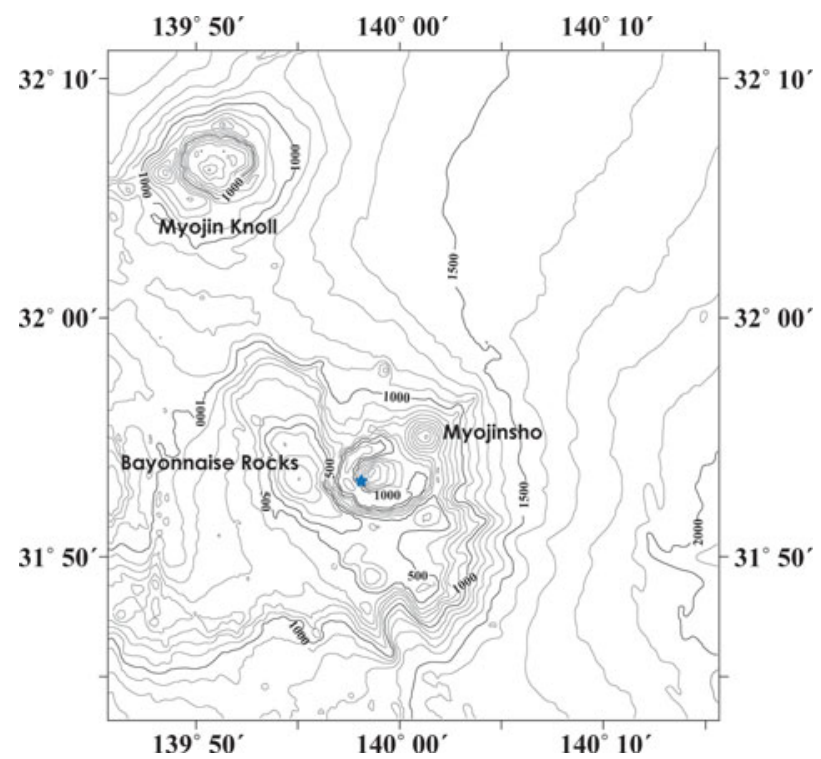

Fig. 1. Bathymetry around Myojinsho and Myojin Knoll. Star indicates the sampling point of the mussels.

In this paper, we report the discovery of a colony of a deep-sea mussel at a hydrothermal vent in Myojinsho. We examined the mussel morphologically and also using mitochondrial DNA sequence and identified it to be B. aduloides. This is an unexpected result because the dominant species of other hydrothermal vents in this area is B. septemdierum and $B$. aduloides has not been previously recorded in hydrothermal vents in the Izu-Ogasawara Arc.

\section{MATERIALS AND METHDDS}

\section{Material examined}

Six specimens were collected by the remotely operated vehicle (ROV) 'Hyper-Dolphin', which was operated by the research vessel (RV) 'Natsushima', at Myojinsho $\left(31^{\circ} 53^{\prime} \mathrm{N} 139^{\circ} 58^{\prime} \mathrm{E}\right.$; Figure 1), at the depth of $900.5 \mathrm{~m}$ on 19 April 2009, during the research cruise NTo9-05. The colony contained 44 mussels of countable size (Figure 2A). They are found to bury a part of their shells into the sediment.

\section{Morphological analysis}

Morphological observations were performed using 2 specimens (shell length: $51.9 \mathrm{~mm}$ and $39.0 \mathrm{~mm}$ ) according to Hashimoto \& Okutani (1994). Shell feature was measured

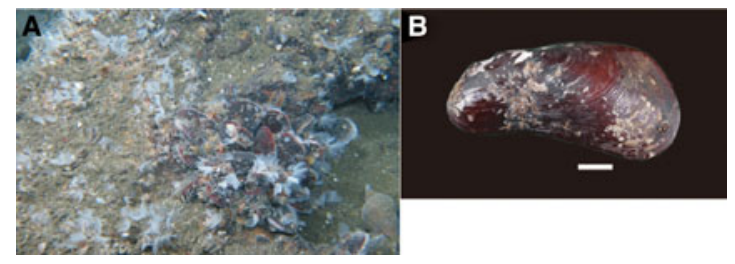

Fig. 2. (A) A picture of the mussel colony in Myojinsho. This image was taken by ROV 'Hyper-Dolphin' in April 2009. White cirri of Neoverruca sp. are observed around the mussels; (B) specimen of Bathymodiolus aduloides. White bar indicates $10 \mathrm{~mm}$. by caliper. Muscle scars and gut were observed under a stereoscopic microscope.

\section{DNA sequencing}

Total DNA was extracted from the gill tissues with DNeasy Blood and tissue kit (Qiagen $\mathrm{GmbH}$, Hilden, Germany). Mitochondrial cytochrome $\mathrm{c}$ oxidase I (COI) was amplified using the universal primers LCO1490: $5^{\prime}$-GGTCAACAAAT CATAAAGATATTGG- $3^{\prime}$ and HCO 2198: TAAACTTCA GGGTGACCAAAAAATCA - 3' (Folmer et al., 1994). The polymerase chain reaction (PCR) was performed using ExTaq (TaKaRa Bio, Otsu, Japan) under the following conditions: $1 \mu \mathrm{l}$ of $100 \mu \mathrm{g}$ genomic DNA was amplified in a $25 \mu \mathrm{l}$ reaction mixture containing $0.08 \mu \mathrm{M}$ dNTP, $0.02 \mu \mathrm{M}$ forward and reverse primers, $2.5 \mu l 10 \times$ ExTaq buffer and $0.625 \mathrm{U}$ of ExTaq DNA polymerase (TaKaRa Bio, Otsu, Japan). Amplification was achieved through 35 cycles of denaturing at $95^{\circ} \mathrm{C}$ for 10 seconds, annealing at $50^{\circ} \mathrm{C}$ for 15 seconds and extension at $72^{\circ} \mathrm{C}$ for 1 minute. PCR products were purified using the QIAquick PCR Purification Kit (Qiagen GmbH, Hilden, Germany). Sequences were determined with an automated sequencer (Applied Biosystems, model $31301 \times 1)$. The obtained sequence was compared using nucleotide - nucleotide BLAST (blastn) with default settings using the DDBJ/EMBL/GenBank database.

\section{Phylogenetic analyses}

Reference sequences of the mussels were obtained from the DDBJ/EMBL/GenBank database (Table 1).

The newly-obtained and reference sequences were aligned using the Clustal W program in MEGA software ver. 3.1 to detect insertion, deletion and base substitution.

The neighbour-joining and maximum parsimony trees were conducted with the MEGA software program ver. 3.1. Kimura's two-parameter model was used for the neighbourjoining tree. Bootstrap replication number was 1000 times for each method.

\section{RESULTS}

\section{Morphological observations}

The Myojinsho mussels exhibit shell and gut features of B. aduloides described in Hashimoto \& Okutani (1994). They have thick, solid and elongate shells, modioliform, inflated, equivalve (Figure $2 \mathrm{~B}$ ). Shell height/length ratio: 0.50 (length $51.9 \mathrm{~mm}$ ), 0.52 (length $39.0 \mathrm{~mm}$ ), width/length ratio: 0.34 (length $51.9 \mathrm{~mm}$ ), 0.33 (length $39.0 \mathrm{~mm}$ ). The umbones subterminal situated at about one-tenth of the shell length. Ligament strong, extending about seven-tenths of dorsal margin length with slightly convex ligament plate. Anterior adductor muscle scar large and posterior adductor muscle scar rounded trapezoid. Gut with a single clockwise loop.

\section{Mitochondrial COI sequence and phylogenetic analyses}

We obtained 667-base pairs (bp) of mitochondrial DNA sequence of COI region from Myojinsho mussel and the 
Table 1. List of sequences used for phylogenetic analyses.

\begin{tabular}{llll}
\hline Species & Accession number & Sampling site & Habitat type \\
\hline Bathymodiolus aduloides & $\mathrm{AB} 170054$ & Iheya Ridge & Vent \\
& $\mathrm{AB} 170055$ & Off Kikaijima Island & Seep \\
& $\mathrm{AB} 170056$ & Off Kikaijima Island & Seep \\
& $\mathrm{AB} 170057$ & Off Kikaijima Island & Seep \\
& $\mathrm{AB} 170058$ & Off Kikaijima Island & Seep \\
& $\mathrm{AB} 170059$ & Off Kikaijima Island & Vent \\
& $\mathrm{AB} 597557$ & Myojinssho (present study) & Vent \\
B. sp. manusensis -JM-2003 & $\mathrm{AB} 101432$ & Manus Basin, PACKMANUS Field E & Vent \\
& $\mathrm{AB} 101433$ & Manus Basin, PACKMANUS Field E & Vent \\
B. sp. & $\mathrm{AB} 101434$ & Manus Basin, PACKMANUS Field E & Vent \\
& $\mathrm{AB} 257539$ & Hine Hina, Lau Basin & Vent \\
& $\mathrm{AB} 257540$ & Hine Hina, Lau Basin & Vent \\
& $\mathrm{AB} 257541$ & Hine Hina, Lau Basin & Vent \\
& $\mathrm{AB} 257543$ & Hine Hina, Lau Basin & Vent \\
& $\mathrm{AB} 255739$ & Off New Zealand & Vent \\
Tamu fisheri & $\mathrm{AB} 255740$ & Off New Zealand & Vent \\
Adipicola pacifica & $\mathrm{AB} 255741$ & Off New Zealand & Vent \\
\hline
\end{tabular}

sequence data were deposited in the DDBJ/EMBL/GenBank databases under the accession number AB597557. A BLAST search revealed that the sequence of the Myojinsho mussel was identical with that of $B$. aduloides collected at the cold seep at Off Kikaijima (DDBJ/EMBL/GenBank accession number $\mathrm{AB} 170058)$. We constructed phylogenetic trees using 430-bp from 21 specimens, including B. aduloides, B. manusensis and unidentified bathymodiolin mussels inhabiting Off New Zealand and Lau Basin, all of which are included in a single clade in the previous studies (Kyuno et al., 2009; Lorion et al., 2010; Miyazaki et al., 2010). Tamu fisheri was added because it was suggested to be phylogenitically close to these species (Lorion et al., 2010; Miyazaki et al., 2010). Adipicola pacifica was used as outgroup. Neighbour-joining and maximum parsimony trees showed the same topology. Tamu fisheri branched first and others formed a single clade consisting of two subclades; Myojinsho mussel formed one subclade with $B$. aduloides of Off Kikaijima and Iheya ridge, and B. manusensis and B. sp. from Lau Basin and New Zealand formed another subclade (Figure 3).

\section{DISCUSSIDN}

In addition to the morphological observations of the shell features, muscle scars, gut and mitochondrial DNA sequence from the COI region showed that the Myojinsho mussel is Bathymodiolus aduloides Hashimoto \& Okutani 1994. It is interesting that the sequence was identical to that of $B$. aduloides of Off Kikaijima. This may indicate gene flow between the two populations. If this is the case, the Kuroshio Current may be involved. Gene flow in Myojinsho and Sagami Bay and/or Suruga Bay is also possible but we could not prove it because no sequence data are available for the mussels from these sites.

Phylogenetic analyses revealed that $B$. aduloides specimens including the Myojinsho mussel form a single subclade and B. manusensis and B. sp. from Lau Basin and New Zealand

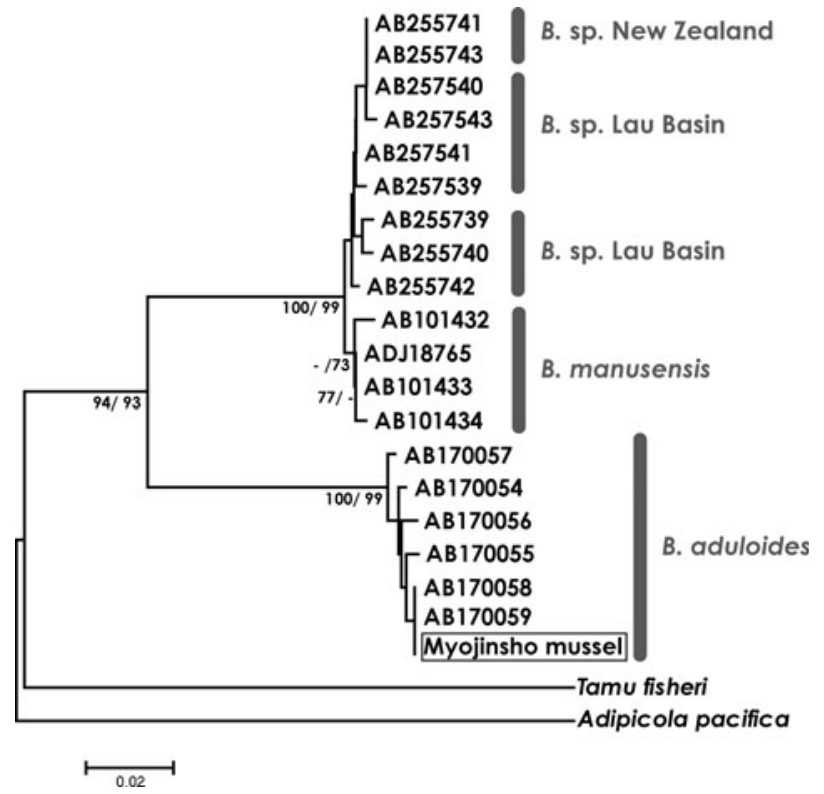

Fig. 3. Phyogenetic relationships of Myojinsho mussel and their relatives based on the COI sequences. The neighbour-joining (NJ) tree was constructed based on the genetic distances calculated according to Kimura's two-parameter method using Adipicola pacifica as an outgroup species. The maximum parsimony (MP) tree presented essentially the same topology as the NJ tree. Only the NJ (left) and MP (right) bootstrap values $>70 \%$ are specified. See Table 1 for accession numbers of specimens.

another subclade. These two subclades formed a single clade supported by high bootstrap values. These results support the previous studies (Kyuno et al., 2009; Lorion et al., 2010; Miyazaki et al., 2010) that proposed the independence of the lineage of $B$. aduloides and $B$. manusensis among Bathymodiolus spp., and similarity of the unidentified mussels of Lau Basin and New Zealand to B. manusensis.

Distribution of $B$. aduloides at Myojinsho is interesting because this species has been recorded mainly from cold 
seeps near Japan, i.e. at Off Kikaijima, Okinoyama Bank in Sagami Bay and Kanasunose Bank in Suruga Bay. Bathymodiolus aduloides has been also recorded in hydrothermal vents but the location is the relatively distant Minami-Ensei Knoll and Iheya Ridge in the mid-Okinawa Trough, an active back-arc basin under extensional stress and in an incipient stage of back-arc spreading related to subduction of the Philippine Sea Plate along the Nansei Shoto Trench. Consequently, this is the first report on the new distribution of B. aduloides at the Izu-Ogasawara area, an island arc that extends longitudinally along the edge of the north-eastern Philippine Sea Plate (Figure 4).

This distribution pattern is similar to those of two other bathymodiolin mussels, B. japonicus and B. platifrons: these mussels inhabit both vents in Okinawa Trough and cold seep in Sagami Bay, of which the distance is approximately $1500 \mathrm{~km}$ (Kyuno et al., 2009). However, as these two species harbour methanotrophic symbionts (Fujiwara et al., 2000), their distribution is limited by availability of methane. As $B$. aduloides harbours thiotrophic symbionts, it seems that the distribution of $B$. japonicus and B. platifrons are limited by chemical condition rather than physical environment.

The distribution pattern of $B$. aduloides is similar to Calyptogena clams, which inhabit both Sagami Bay and Iheya Ridge in Okinawa Trough. It is also interesting that both harbour thiotrophic symbionts and have behaviour to bury the shells into sediment. However, they have different strategies for sulphide uptake: Calyptogena clams bury themselves deeper than $B$. aduloides inserting the foot deeply into the sulphide-rich sediment because they absorb sulphide from their foot and transport it to the symbionts in the gills.
For this purpose, they have evolved special haemoglobin (Childress et al., 1993; Goffredi \& Barry, 2002). Thus, they must inhabit the place where sulphide is in the sediment. Indeed, it is reported that Calyptogena soyoae inhabit a location where pore water containing hydrogen sulphide exists in the sedimentary layer (Hashimoto et al., 1995; Tsunogai et al., 1996). In contrast, B. aduloides do not have such carrier protein and they must absorb hydrogen sulphide in the water, not in the sediment, through the gill. In this context, Calyptogena clams are rather similar to vestimentiferan tubeworms, which absorb sulphide in the sediment (Julian et al., 1999).

Bathymodiolus septemdierum is not found at Myojinsho, whereas they inhabit at the depth of $1200-1300 \mathrm{~m}$ in Myojin Knoll, only $20 \mathrm{~km}$ distance from Myojinsho (Figure 1). It is interesting that B. septemdierum and B. aduloides do not show sympatric distribution although they are congeners harbouring thiotrophic symbionts. Concerning sulphur isotopic composition of soft tissue of B. septemdierum and $B$. aduloides, the former is similar to hydrogen sulphide in the hydrothermal fluids and the sulphide minerals in the chimney and sediments around their habitats, whereas the latter is similar to the hydrogen sulphide derived from sulphate in the seawater, dissimilarly reduced by sulphatereducing bacteria (Yamanaka et al., 2000). Thus, it is considered that the reason why $B$. septemdierum and $B$. aduloides show allopatric distribution is that those mussels use a different source of sulphide. Indeed, at the eastern part of Myojin Knoll, there are many active chimneys and brecciated massive sulphide (Iizasa et al., 1997), around which many large and dense colonies of $B$. septemdierum

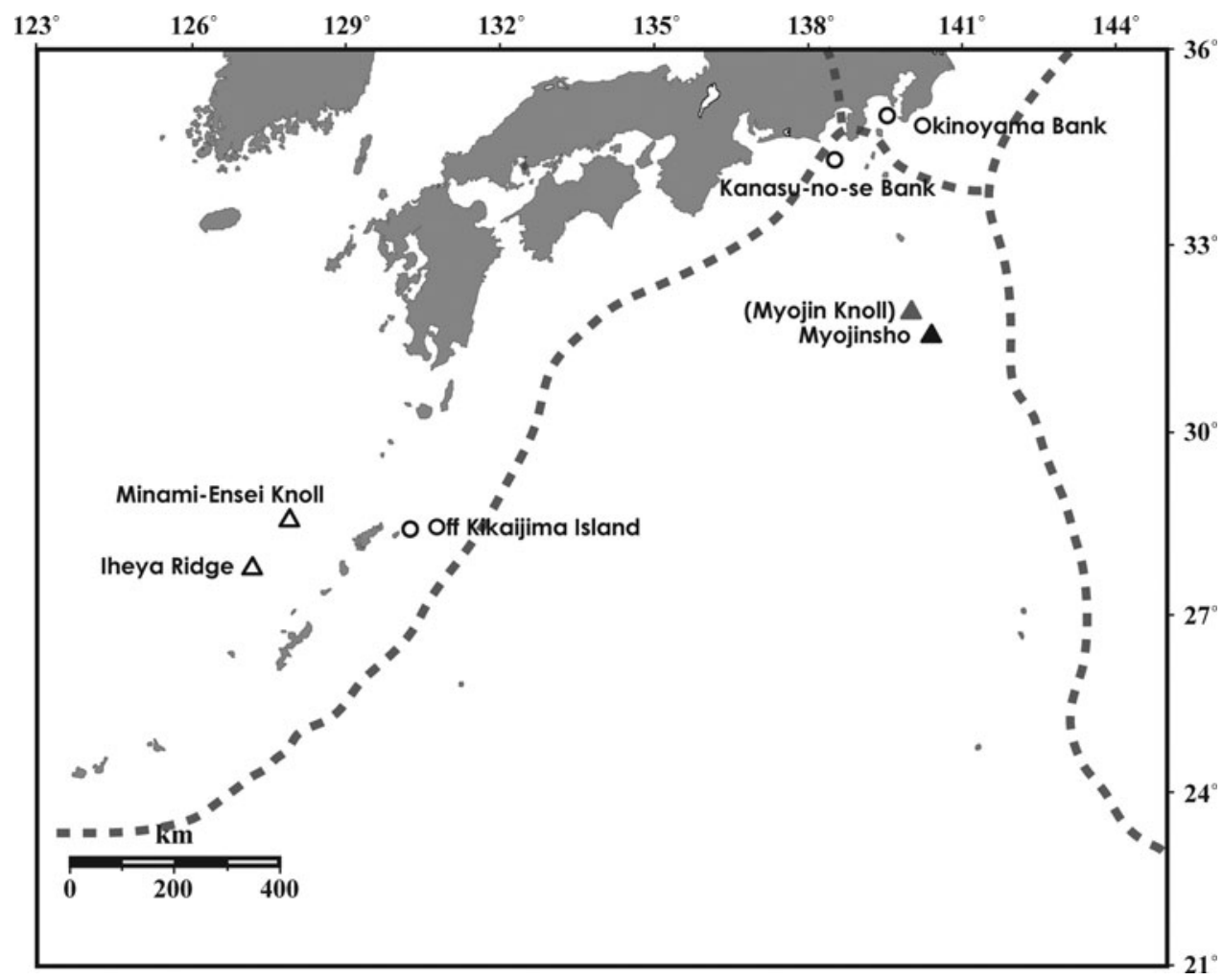

Fig. 4. Habitat location of Bathymodiolus aduloides: closed triangle indicates the location of the present study, Myojinsho. Previously reported habitats are indicated by open triangles (hydrothermal vent) and open circle (cold seep). Myojin Knoll (grey triangle) was also shown as the reference of the distance although $B$. aduloides has not been found there. Dashed lines indicate the plate boundaries. 
are found, forming rich fauna with the barnacle Neoverruca sp. and a number of the hydrothermal vent-specific crab Gandalfus yunohana (Kojima, 2002). In contrast, Myojinsho seafloor is mainly occupied by boulder to pebble-sized rocks covered thinly with sediment (Iizasa et al., 1992), and we did not find hydrothermal vent fluid from chimneys. Therefore, sulphide supply may not be sufficient for B. septemdierum. The population of Neoverruca sp. and G. yunohana which is also likely to be dependent on hydrothermal fluid (Kojima, 2002) was also poor at Myojinsho. Instead, numerous bivalves of the family Pectinidae were observed at the sandy bottom of Myojinsho; it has not been recorded at Myojin Knoll. Thus, species composition and geological character are different between the two calderas despite the close distance, and the difference is likely to be due to the difference of the chemical environments.

It is also possible that periodic eruptions destroyed the previous biota of Myojinsho and B. aduloides, which has been carried from Okinawa Trough and some other locations, and has settled into the open niche. In this case, B. septemdierum may appear in Myojinsho in the future. Thus, Myojinsho offers a good model to investigate the succession of a hydrothermal vent-specific community, and continuous observation should be performed.

\section{ACKNDWLEDGEMENTS}

We thank the crew of RV 'Natsushima' and operation team of ROV 'Hyper-Dolphin' for their help during the cruise NTo9-05.

\section{REFERENCES}

Childress J.J., Fisher C.R., Favuzzi J.A., Arp A.J. and Oros D.R. (1993) The role of a zinc-based, serum-borne sulphide-binding component in the uptake and transport of dissolved sulphide by the chemoautotrophic symbiont-containing clam Calyptogena elongata. Journal of Experimental Biology 179, 131-158.

Distel D.L., Baco A.R., Chuang E., Morrill W., Cavanaugh C. and Smith C.R. (2000) Do mussels take wooden steps to deep-sea vents? Nature $403,725-726$.

Felbeck H. (1983) Sulfide oxidation and carbon fixation by the gutless clam Solemya reidi: an animal-bacteria symbiosis. Journal of Comparative Physiology 152, 3-11.

Fiske R.S., Cashman K.V., Shibata A. and Watanabe K. (1998) Tephra dispersal from Myojinsho, Japan, during its shallow submarine eruption of 1952-1953. Bulletin of Volcanology 59, 262-275.

Folmer O., Black M., Hoeh W., Lutz R. and Vrijenhoek R. (1994) DNA primers for amplification of mitochondrial cytochrome $\mathrm{c}$ oxidase subunit I from diverse metazoan invertebrates. Molecular Marine Biology and Biotechnology 3, 294-299.

Fujiwara Y., Takai K., Uematsu K., Tsuchida S., Hunt J.C. and Hashimoto J. (2000) Phylogenetic characterization of endosymbionts in three hydrothermal vent mussels: influence on host distributions. Marine Ecology Progress Series 208, 147-155.
Goffredi S.K. and Barry J.P. (2002) Species-specific variation in sulfide physiology between closely related vesicomyid clams. Marine Ecology Progress Series 225, 227-238.

Hashimoto J. and Okutani T. (1994) Four new mytilid mussels associated with deep-sea chemosynthetic communities around Japan. Venus 53, $61-83$.

Hashimoto J., Ohta S., Fujikura K., Fujiwara Y. and Sukizaki S. (1995) Life habitat of vesicomyid clam, Calyptogena soyoae, and hydrogen sulfide concentration in interstitial waters in Sagami Bay, Japan. Journal of Oceanography 51, 341-350.

Iizasa K., Yuasa M. and Yokota S. (1992) Mineralogy and geochemistry of volcanogenic sulfides from the Myojinsho submarine caldera, the Shichito-Iwojima Ridge, Izu-Ogasawara Arc, north-western Pacific. Marine Geology 108, 39-58.

Iizasa K., Naka J., Yuasa M. and Fiske R.S. (1997) Sulfide chimneys and massive sulfide at Myojin knoll caldera, Izu-Ogasawara arc. JAMSTEC Journal of Deep Sea Research 13, 443-456. [In Japanese with English abstract.]

Julian D., Gaill F., Wood E., Arp A.J. and Fisher C.R. (1999) Roots as a site of hydrogen sulfide uptake in the hydrocarbon seep vestimentiferan Lamellibrachia sp. Journal of Experimental Biology 202, 22452257.

Kojima S. (2002) Deep-sea chemoautosynthesis-based communities in the north-western Pacific. Journal of Oceanography 58, 343-363.

Kyuno A., Shintaku M., Fujita Y., Matsumoto H., Utsumi M., Watanabe H., Fujiwara Y. and Miyazaki J.-I. (2009) Dispersal, differentiation of deep-sea mussels of the genus Bathymodiolus (Mytilidae, Bathymodiolinae). Journal of Marine Biology 72. Doi:10.1155/2009/ 625672 .

Lorion J., Buge B., Cruaud C. and Samadi S. (2010) New insights into diversity and evolution of deep-sea Mytilidae (Mollusca: Bivalvia). Molecular Phylogenetics and Evolution 57, 71-83.

Miyazaki J-I., Martins LdO., Fujita Y., Matsumoto H. and Fujiwara Y. (2010) Evolutionary process of deep-sea Bathymodiolus mussels. Plos One 5, 1-11

Tsunogai U., Ishibashi J., Wakita H., Gamo T., Masuzawa T., Nakatsuka T., Nojiri Y. and Nakamura T. (1996) Fresh water seepage and pore water recycling on the seafloor: Sagami Trough subduction zone, Japan. Earth and Planetary Science Letters 138, 157-168.

Van Dover C.L., German C.R., Speer K.G., Parson L.M. and Vrijenhoek R.C. (2002) Evolution and biogeography of deep-sea vent and seep invertebrates. Science 295, 1253-1257.

and

Yamanaka T., Mizota C., Maki Y., Fujikura K. and Chiba H. (2000) Sulfur isotope composition of soft tissues of deep-sea mussels, Bathymodiolus spp., in Japanese waters. Benthos Research 55, 63-68.

\section{Correspondence should be addressed to:}

T. Koito

College of Bioresource Sciences

Nihon University

1866 Kameino, Fujisawa, Kanagawa, 252-0880, Japan

email: koito.tomoko@nihon-u.ac.jp 